\title{
Spatial dynamics of the noble crayfish (Astacus astacus, L.) in the Paklenica National Park
}

\author{
S. Hudina ${ }^{(1)}$, I. Maguire ${ }^{(1)}$, G.I.V. Klobučar ${ }^{(1)}$ \\ Received May 31, 2005 / Reçu le 31 mai 2005 \\ Revised February 18, 2008 / Révisé le 18 février 2008 \\ Accepted March 11, 2008 / Accepté le 11 mars 2008
}

\section{ABSTRACT}

Key-words: noble crayfish, spatial dynamics, Paklenica National Park

\begin{abstract}
The aim of this work was to analyse the spatial dynamics of a noble crayfish population inhabiting the Velika Paklenica Stream (Paklenica National Park, Croatia). The study was conducted in July 2000, and between March and September 2002. Crayfish were trapped by baited LiNi traps and hand-made traps at two localities over 25 nights. We recorded the precise position of the captured crayfish, their sex, and total length. Crayfish were individually marked and then released back into the stream at the same spot where they were caught. Spatial analyses included determination of movement direction, distribution type, home range, total distance travelled, and mean daily movement. A mean home range of approximately $19 \mathrm{~m}$ was calculated. No difference in home range between the sexes was found. There was a large individual variation in the extent of movement without any effect of sex or size.
\end{abstract}

\section{RÉSUMÉ}

\section{Dynamique spatiale des écrevisses à pieds rouges (Astacus astacus L.) dans le Parc National Paklenica}

\author{
Mots-clés : \\ écrevisse à \\ pieds rouges, \\ dynamique \\ spatiale, Parc \\ National \\ Paklenica
}

L'objectif de notre recherche était l'analyse de la dynamique spatiale de la population d'écrevisses à pieds rouges dans la rivière Velika Paklenica située dans le Parc National Paklenica, en Croatie. La recherche a été menée en juillet 2000 et entre mars et septembre 2002. Les écrevisses ont été capturées avec des nasses LiNi et des nasses faites à la main, dans deux localités, pendant 25 nuits au total. Nous avons relevé la position précise des écrevisses capturées, leur sexe et leur longueur totale. Les écrevisses ont été marquées individuellement, avec des trous dans les uropodes et le telson, et relâchées ensuite. L'analyse spatiale a compris la détermination de la direction de mouvement, du type de distribution spatiale, de la taille de l'habitat, de la distance parcourue et du déplacement moyen quotidien. La distribution des écrevisses, comme on pouvait s'y attendre, est agrégée spatialement. La dimension moyenne de l'habitat de $19.03 \mathrm{~m}$ correspond à des données trouvées dans la littérature, mais aucune différence entre les sexes n'a été trouvée. 


\section{INTRODUCTION}

Information about animal movement and activity contributes to the understanding of their habitat requirements, patterns of resource utilisation and interspecific interactions (Sutherland, 1996). Activity pattern, home range and spatial behaviour, along with population densities and size structure, are good indicators of population viability and persistence (Acosta and Perry, 2001), and are particularly important when considering the effects of habitat disturbances.

Our research was focused on the spatial dynamics of the noble crayfish (Astacus astacus (Linnaeus, 1758)). The noble crayfish is one of the four native European crayfish species inhabiting Croatian freshwater habitats, and it is protected by Croatian Law (Narodne Novine, 70/05; Narodne Novine, 7/06). It is naturally distributed in rivers belonging to the Black Sea Basin, forming both river and lake populations. It also occurs in the Adriatic Sea Basin, where its presence is of anthropogenic origin (Maguire and Gottstein-Matočec, 2004).

Although the ecology of the noble crayfish and other crayfish species is relatively well studied, up until the last few decades insufficient attention has been given to spatial dynamics of crayfish species in their natural habitat. The literature provides a few reports on the spatiotemporal activity of the native European species, such as the white-clawed crayfish (Gherardi et al., 1998; Acquistapace and Gherardi, 1999; Barbaresi et al., 1999). In recent years, a significant amount of research has been conducted in relation to movement patterns of invasive crayfish species in Europe (Gherardi et al., 1999; 2000; 2002; Barbaresi et al., 2004; Aquiloni et al., 2005; Barbaresi and Gherardi, 2006; Bubb et al., 2004; 2006a) and differences in spatial behaviour between invasive and native species (Bubb et al., 2006b). Only a few authors have described movement patterns of small samples of Astacus astacus in natural habitats (Bohl, 1999; Schütze et al., 1999), using radio telemetry.

The aim of our research was to describe noble crayfish movement and distribution using a standard capture-mark-recapture technique, and give a comparative set of data on the spatial dynamics of this species in its natural habitat.

\section{MATERIAL AND METHODS}

\section{> STUDY SITES}

Velika Paklenica Stream is situated in the Paklenica National Park, on the southern slopes of the Velebit Mountain (Figure 1). The source of this karstic stream is located $1200 \mathrm{~m}$ above sea level. The stream is characterised as a periodical torrent watercourse with a total stream length of $14 \mathrm{~km}$; the lower part usually dries out during the summer months. It partly runs through a deciduous forest, dominated by hornbeam (Carpinus betulus) and Downy oak (Quercus pubescens) forest. The highest flow of $4.45 \mathrm{~m}^{3} / \mathrm{s}$ was recorded in February, while the lowest one, of $0.006 \mathrm{~m}^{3} / \mathrm{s}$, was in November (Božičević, 1999). The substrate consists mostly of rocks, but there are sand and pebbles in the middle and lower parts, and in places with a slower current. For our study we chose two localities - Anića luka, at $270 \mathrm{~m}$ above sea level and Hrast, at $320 \mathrm{~m}$ above sea level. Hrast is characterised by relatively shallow sections intercepted with pools of greater depth, while Anića luka has less fluctuation in depth and current velocity. The latter site had fully dried out in August and partially in September 2002, while Hrast, positioned in the upper part of the stream, did not dry out.

\section{> CAPTURE AND MARKING}

Crayfish were trapped using baited LiNi traps (Westman et al.,1978) and hand-made traps (Maguire, 2002), in July 2000, and between March and September 2002. Trapping was performed in two localities over 4-7 sequential nights, reaching a total of 25 nights. Baited traps were set along stream banks at $10-\mathrm{m}$ intervals in stretches of approximately 


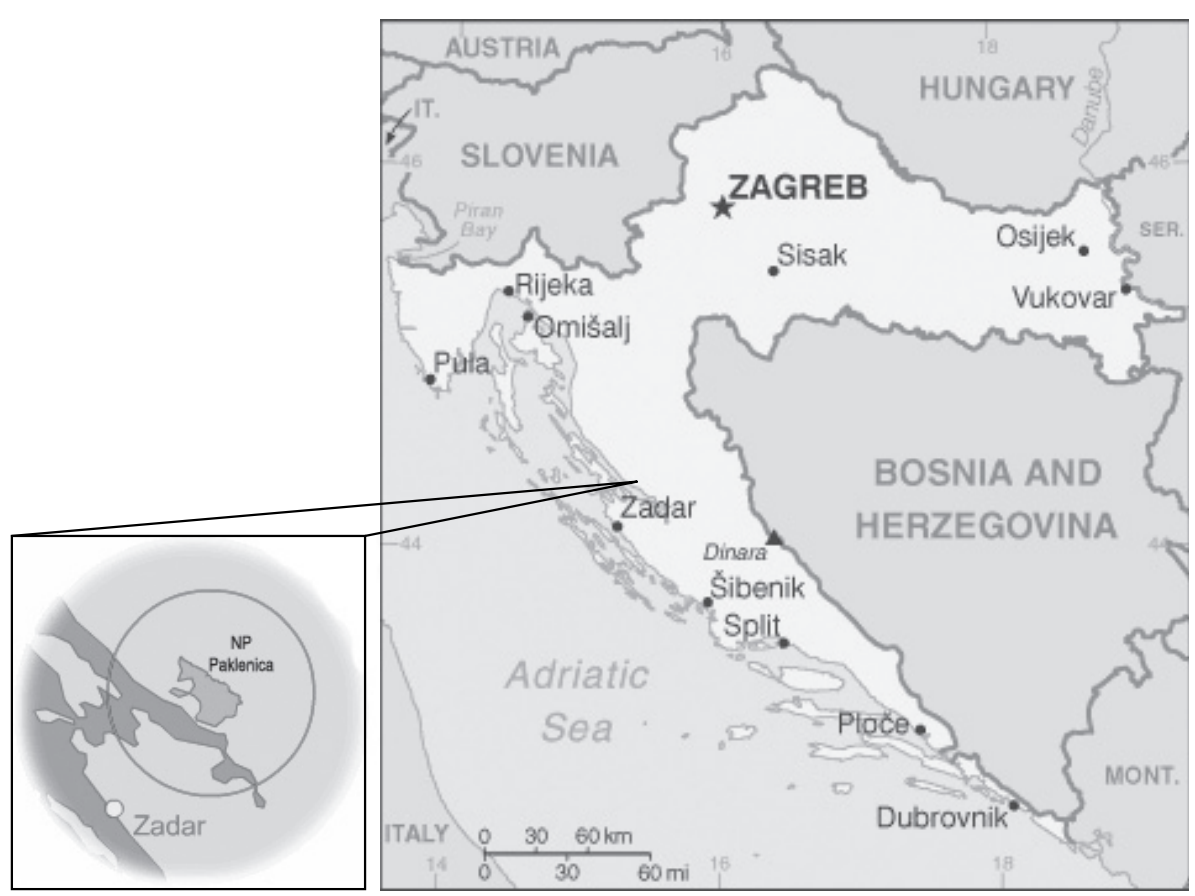

\section{Figure 1}

Position of the Velika Paklenica Stream and the Paklenica National Park within Croatia (adapted from http://www.lib.utexas.edu/maps/cia07/croatia_sm_2007.gif).

\section{Figure 1 \\ Situation de la rivière Velika Paklenica et du Parc National Paklenica en Croatie (adapté d'après http://www.lib.utexas.edu/maps/cia07/croatia_sm_2007.gif).}

$100 \mathrm{~m}$ and left there overnight. We recorded the precise position of the captured crayfish, their sex and total length - TL (using a Vernier calliper). They were individually marked according to Guan (1997) by piercing a hole in the telson and/or in the uropods. Codes provide identification of each marked individual - by different combinations of piercing positions on the uropods/telson more than 10800 codes can be obtained, which makes this method particularly useful for large sample size analysis. Codes can be observed through several moults (two to three). Then, crayfish were released back into the stream, at the same spot where they were captured.

\section{$>$ DATA ANALYSES}

Specimens captured by LiNi traps were considered in spatial analyses. As the LiNi traps (mesh size $14 \mathrm{~mm}$ ) used are size-selective (Hogger, 1988), animals captured by them were longer than $5 \mathrm{~cm} \mathrm{TL}$, and could be easily marked and therefore be relevant for the abovementioned analyses. On the contrary, the crayfish captured by hand-made traps were smaller $(<5 \mathrm{~cm} \mathrm{TL})$ and difficult to mark because of their small size. Analyses included determination of movement direction (upstream, downstream), distribution type, home range, total distance travelled and mean daily movement.

Distribution type was calculated using a coefficient of dispersion (Variance-to-Mean-Ratio), Morisita's index of dispersion and the standardised Morisita's index of dispersion (Krebs, 1989). Prior to applying the dispersion coefficient (CD), a $\chi^{2}$ test was used to analyse whether the distribution differed from theoretical (Poisson) distribution. We examined pooled data from both localities collected in research periods of 6 and 4 nights, and data from each locality separately for the period of 4 nights. 
The coefficient of dispersion shows the ratio of mean number of individuals per sampling unit (e.g. trap) and variance of observed distribution frequencies per sampling unit $\left(C D=\mathrm{s}^{2} / \bar{x}\right)$. This classification can be used only when a ratio is statistically significant (Pielou, 1977; according to Okubo and Levin, 2001). The coefficient of dispersion is based on the observation that in a random pattern, described by Poisson distribution, the variance is equal to the mean. Therefore, the dispersion coefficient is 1 . If the dispersion coefficient is larger than 1, distribution is aggregated/grouped, and if it is smaller than 1, distribution is regular or uniform. The dispersion coefficient is affected by sample size, although Myers (1978) (according to Krebs (1989)) demonstrated that the variance-to-mean ratio was only weakly affected by population density and is a good measurement of dispersion.

Morisita's index of dispersion, summarised by Krebs (1989), is based on quadrat counts counts of the number of individuals recorded in the $n$ quadrats of defined size and shape (e.g. LiNi trap). The standardised Morisita's index is an improved Morisita's index, independent of population density and sample size. For this coefficient random distribution equals 0 and aggregated distribution is over 0 , while regular/uniform distribution is below 0 .

Home range was measured as the maximum distance (the furthest trap that the animal was caught in) from the initial trap. The initial trap was defined as the trap in which a certain crayfish was caught at least twice during the research period. Therefore, only individuals caught at least twice in the initial trap, and at least once in another trap, were used in home range analyses. The mean value of home range was multiplied by the average stream width in order to calculate the average surface area used by a crayfish.

Crayfish movement was calculated under the assumption that animals were moving linearly, therefore passing the minimal possible distance between traps. The sum of all minimal distances covered by a given crayfish during the research period is defined as the total distance travelled.

Mean daily movement of a given marked crayfish was calculated as the distance between the first and the last capture (total distance travelled) divided by the number of days between these events for marked crayfish (Robinson et al., 2000).

Statistical analyses were performed using the program STATISTICA 5.0. Student's t-tests and Pearson's correlation were used when data were distributed normally or in analyses where the sample size was larger than 90. Otherwise, nonparametric statistical tests (MannWhitney U test and Spearman's Rank correlation test) were applied.

\section{RESULTS}

A total of 1144 crayfish was captured (Table I), of which 838 specimens were taken for further analyses (397 females and 441 males). Out of 838 crayfish, 272 were recaptured $(32.5 \%$ of the analysed population). The sex ratio fluctuated seasonally at both localities with an overall sex ratio in Anića luka of 1:1.1 (females:males), and 1:0.81 in Hrast.

The $\chi^{2}$ test indicated a statistically significant difference from Poisson distribution for the research periods of 6 nights and 4 nights, respectively $\left(\chi^{2}(6\right.$ nights $)=142.30$, df $=30$; $\chi^{2}(4$ nights $\left.)=126.20, \mathrm{df}=50 ; p<0.01\right)$. Afterwards, a dispersion coefficient (CD) was calculated for both research periods. As both coefficients were larger than 1, the dispersion coefficient indicated grouped or aggregated distribution. Aggregated distribution was confirmed by Morisita's index of dispersion and the standardised Morisita's index as well (Table II). Also, we examined crayfish distribution over 4 nights at each locality. For Anića luka the $C D$ was $1.771\left(\chi^{2}=56.676, d f=32, p<0.01\right)$, while for Hrast it was $3.319\left(\chi^{2}=\right.$ 72.012, $\mathrm{df}=22, \mathrm{p}<0.01$ ).

To determine home range we used only 30 crayfish that fitted the postulated definition (see Material and methods). The calculated mean home range was $19.03 \mathrm{~m}$, which, multiplied by the average stream width of $3.36 \mathrm{~m}$, gave an average surface area of $63.94 \mathrm{~m}^{2}$ covered by a crayfish. We did not find a statistically significant difference in home range between the sexes $(t=-0.499 ; d f=28, p=0.621)$. 


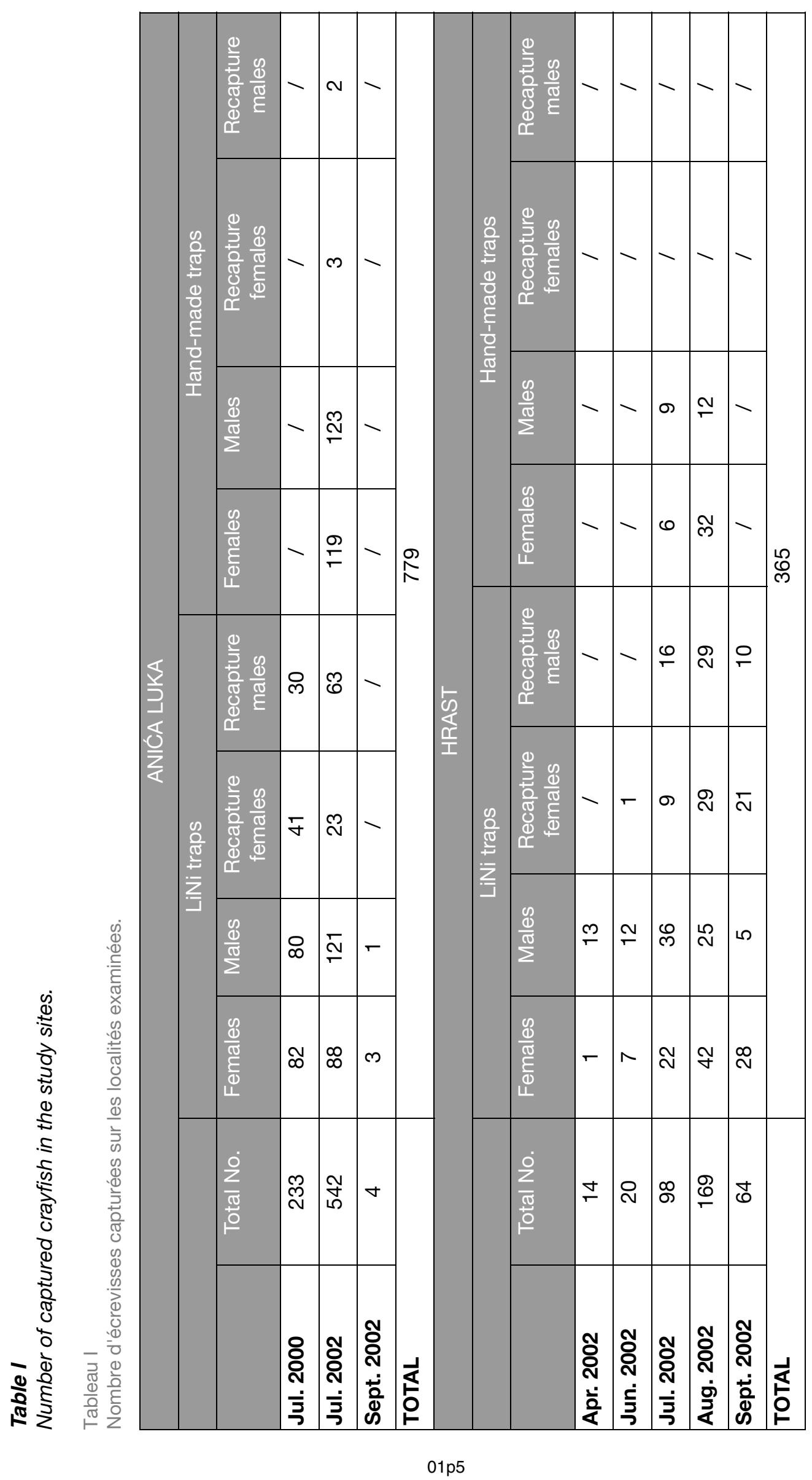




\section{Table II}

Results of the different estimations of the dispersion coefficient for the periods of 4 and 6 nights.

Tableau II

Résultats de l'estimation du type de distribution spatiale pour la période de 4 et 6 nuits.

\begin{tabular}{|l|c|c|c|}
\hline Period of & $\begin{array}{c}\text { Dispersion coefficient } \\
(\mathrm{CD})\end{array}$ & Morisita index & $\begin{array}{c}\text { Standardised Morisita } \\
\text { index }\end{array}$ \\
\hline $\mathbf{4}$ nights & 2.524 & 1.172 & 0.501 \\
\hline $\mathbf{6}$ nights & 4.743 & 1.325 & 0.505 \\
\hline
\end{tabular}

\section{Table III}

Results of descriptive statistical analyses for total distance travelled and mean daily movement in the study sites.

\section{Tableau III}

Résultats d'analyse descriptive statistique des distances parcourues et mouvements quotidiens moyens sur les localités examinées.

\begin{tabular}{|l|c|c|c|c|c|}
\hline \multicolumn{5}{|c|}{ ANIĆA LUKA } \\
\hline & $\begin{array}{c}\text { No. of } \\
\text { animals }\end{array}$ & Mean & Minimum & Maximum & $\begin{array}{r}\text { Standard } \\
\text { deviation }\end{array}$ \\
\hline $\begin{array}{l}\text { Total distance travelled } \\
\text { (m) }\end{array}$ & 70 & 15.296 & 1.000 & 73.100 & 17.092 \\
\hline $\begin{array}{l}\text { Mean daily movement } \\
\text { (m/night) }\end{array}$ & 70 & 7.616 & 0.500 & 71.000 & 9.869 \\
\hline & $\begin{array}{c}\text { No. of } \\
\text { animals }\end{array}$ & Mean & Minimum & Maximum & $\begin{array}{l}\text { Standard } \\
\text { deviation }\end{array}$ \\
\hline $\begin{array}{l}\text { Total distance travelled } \\
\text { (m) }\end{array}$ & 58 & 12.731 & 1.500 & 63.700 & 12.628 \\
\hline $\begin{array}{l}\text { Mean daily movement } \\
\text { (m/night) }\end{array}$ & 23 & 5.175 & 0.500 & 13.000 & 3.084 \\
\hline
\end{tabular}

Descriptive statistical analyses of the total distance travelled and mean daily movement at the examined localities are presented in Table III, and in Figures 2 to 5.

There was no statistically significant difference between the localities, or crayfish sex or size $(T L)$ in total distance travelled or mean daily movement (sex - total distance travelled: $t=$ $0.266, \mathrm{df}=126, \mathrm{p}=0.791$; locality - total distance travelled: $\mathrm{t}=0.948, \mathrm{df}=126, \mathrm{p}=0.345$; crayfish size - total distance travelled: $t=0.850, d f=3, p=0.457$; sex - mean daily movement: $t=1.083, d f=91, p=0.282$; locality - mean daily movement: $t=1.164, d f=91$, $p=0.247$, crayfish size - mean daily movement: $t=-1.741$, $d f=2, p=0.224$ ). A significant statistical difference was found in size between the sexes $(t=3.644$, $d f=124, p=0.0004)$, and the female to male ratio between localities $(t=-3.299$, $d f=124, p=0.001)$.

For each locality, crayfish size was correlated with movement variables (total distance travelled and mean daily movement) using the nonparametric Spearman Rank correlation test. No significance was found. In Anića luka, a significant difference in total length between 


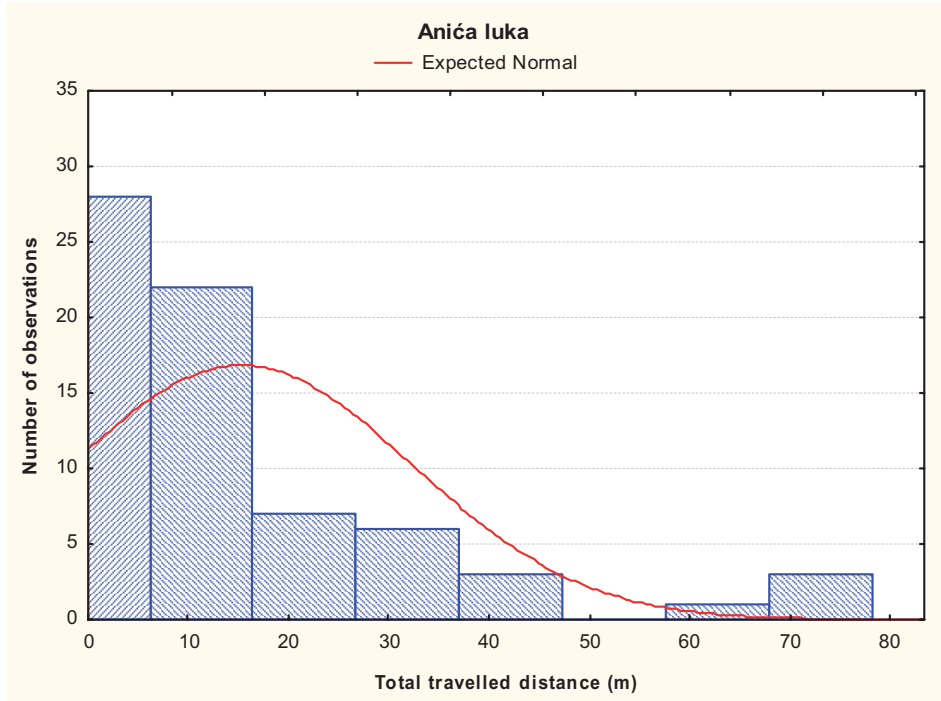

Figure 2

Histograms of total distance travelled in Anića luka.

Figure 2

Histogramme des distances parcourues au site Anića luka.

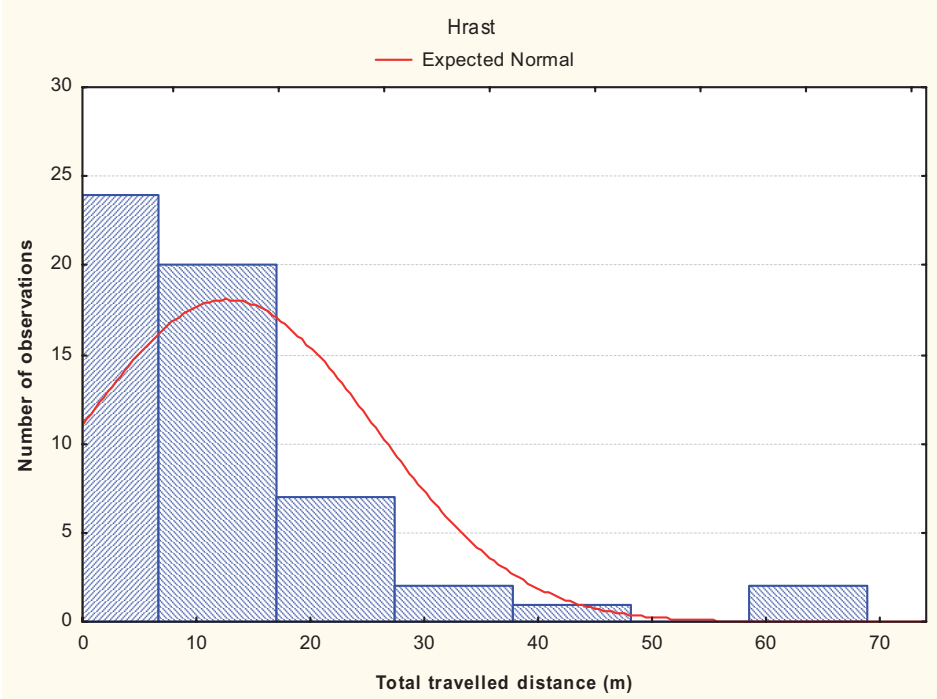

Figure 3

Histograms of total distance travelled in Hrast.

\section{Figure 3}

Histogramme des distances parcourues au site Hrast.

the sexes was recorded $(U=370.500, Z=2.353, P<0.05)$, while in Hrast there was no statistically significant difference $(U=59, Z=1.033, P>0.05)$.

When possible, we recorded movement direction. Upstream movement was more frequently recorded at both localities. There was no statistically significant difference in measured variables (sex, total distance travelled and mean daily movement) for movement direction. However, the difference between crayfish size in the movement direction was statistically significant 


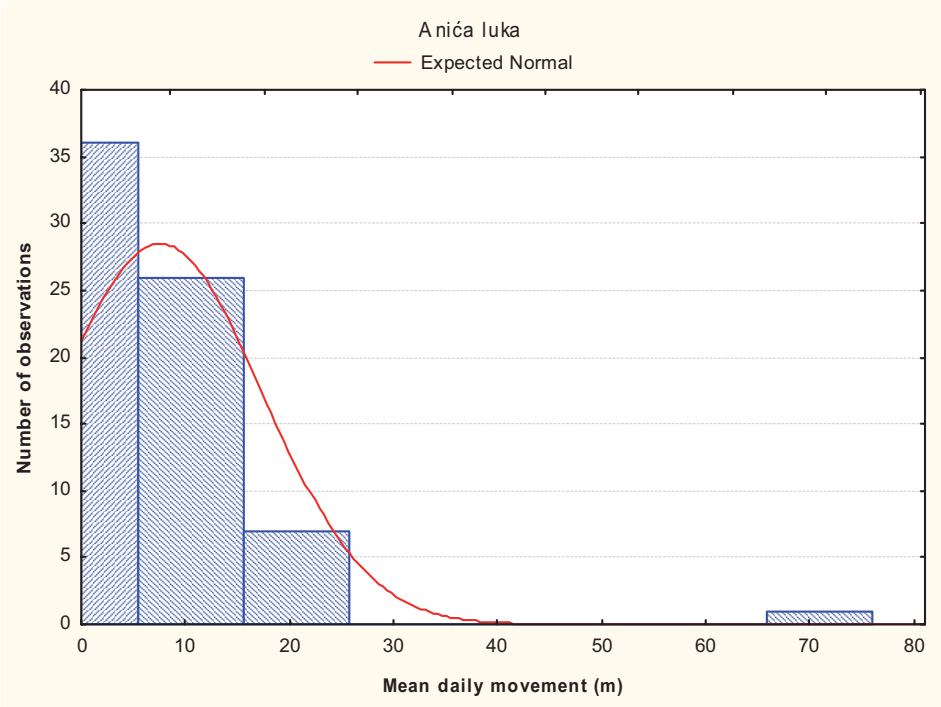

\section{Figure 4}

Histograms of mean daily movement in Anića luka.

\section{Figure 4}

Histogramme des mouvements quotidiens moyens au site Anića luka.

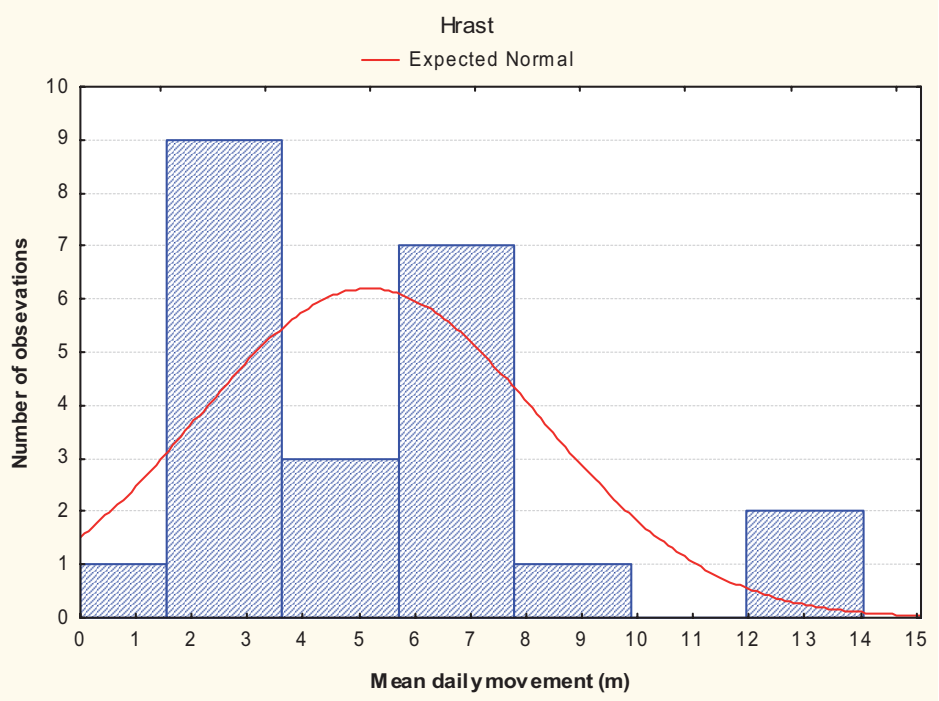

\section{Figure 5}

Histograms of mean daily movement in Hrast.

\section{Figure 5}

Histogramme des mouvements quotidiens moyens au site Hrast.

$(U=159, Z=2.009, P>0.05)$. A significant positive correlation was recorded between these variables (crayfish size-movement direction: Spearman Rank, $r_{s}=0.287, P>0.05$ ).

\section{DISCUSSION}

Since there are only a few papers describing movement patterns of a relatively small number of native crayfish species (Gherardi et al., 1998; Acquistapace and Gherardi, 1999; Barbaresi 
et al., 1999; Robinson et al., 2000), especially Astacus astacus (Bohl, 1999; Schütze et al., 1999), our study aimed to incorporate as many individuals as possible in order to get a better understanding of the spatial behaviour of noble crayfish.

The chosen mark-recapture approach and trapping method (LiNi traps of specific mesh size) yielded 838 specimens for spatial analyses, out of 1144 captured crayfish altogether.

The sex ratio fluctuated seasonally, with an overall sex ratio of 1:1.1 and 1:0.81 (females:males) in Anića luka and Hrast, respectively. Differences in sex ratios over seasons can mainly be attributed to differences in the activity pattern of males and females (Westin and Gydemo, 1989). In the research by Brown and Bowler (1977) on Austropotamobius pallipes, and Lucić (2004) and Faller (2006) on Astacus astacus, there was always a higher number of trapped males than females, regardless of the season. In our research we found no statistically significant difference in the number of trapped males and females, which corresponds to the results obtained by Skurdal et al. (1992). We recorded a significant difference in crayfish size (total length) between the sexes. Males were slightly larger than females, probably due to sexual dimorphism (Abrahamsson, 1966; Skurdal and Taugbøl, 2002).

The distribution of crayfish belonged, as expected, to grouped/aggregated distribution. The presence of crayfish, among the other factors, is strongly dependent on the structure of the stream bottom (Niemi, 1977; Bohl, 1987; Laurent, 1988; Foster, 1995; Byrne et al., 1999). Benthic substrate composition strongly influences spatial distribution of noble crayfish (Odelström, 1988; Skurdal et al., 1988; Skurdal and Taugbøl, 2002), therefore populations of higher density can be observed in places with greater morphometrical and structural variability of the substrate (Bohl, 1997). As the bed of the Velika Paklenica Stream is mostly unfavourable for noble crayfish, with predominantly large limestone rocks and fast current, localities with slower current, and sand and leaf deposits are the most densely populated. Higher values of the dispersion coefficient in Hrast indicate higher patchiness at this locality in terms of favourable habitat availability.

Spatial analyses were performed under the assumption of linearity. Although this does not reflect the real movement pattern since data gathering performed by the mark-recapture method is not continuous, it is a good approximation of movement and spatial distribution. Radio-telemetry has the advantage of studying movement in a continuum without disturbance and provides finer-scale information than mark-recapture techniques (Bubb et al., 2002). However, only a small number of individuals can be analysed due to the high costs of the equipment (Bohl, 1999; Schütze et al., 1999), which is one of the major drawbacks of this method. Therefore, a combination of both methods, as applied by Robinson et al. (2000) on ranging behaviour of the white-clawed crayfish Austropotamobius pallipes, would be optimal for studying spatial ecology of crayfish.

The home range of $19.03 \mathrm{~m}$ recorded in our study corresponds to literature data suggesting that, when food is abundant, the majority of crayfish (approximately $82 \%$ ) can be found within $25 \mathrm{~m}$ from their hiding places (Cukerzis, 1988). We did not find any significant difference in the home range between the sexes, although Cukerzis (1988) and Bohl (1999) showed a higher average home range in males. Differences between the sexes in the home range were also not found for signal crayfish (Bubb et al., 2002; 2004). The average surface area calculated from the home range is a valuable parameter when studying populations of the same species in different environments (rivers of different width) (Bubb et al., 2002)

A considerable individual variation in movement (both total distance travelled and mean daily movement) was observed at both localities. In Anića luka, the mean values of total distance travelled and mean daily movement were $15.3 \mathrm{~m}$ and $7.6 \mathrm{~m}$, respectively. In Hrast, the values were $12.7 \mathrm{~m}$ and $5.2 \mathrm{~m}$, respectively. Bohl (1999) showed that small movement ranges were typical of crayfish accustomed to their familiar place. The majority of observed total distances travelled were within the range of $30 \mathrm{~m}$ at both localities, while a relatively small proportion of animals covered greater distances, up to $73.1 \mathrm{~m}$ in Anića luka and $63.7 \mathrm{~m}$ in Hrast. Mean daily movement was most frequently observed in the range of $10 \mathrm{~m}$ per night. In Hrast, crayfish travelled a maximum of $13 \mathrm{~m}$ per night, which is relatively small compared 
with $71 \mathrm{~m}$ per night in Anića luka. Hrast is situated in the upper part of the stream, with higher variation in terrain slope and current velocity, and a higher proportion of limestone rocks in the substrate. These conditions probably influence the range of crayfish movement, although not significantly (no significant difference between localities was found for total distance travelled or mean daily movement).

Neither crayfish size nor sex significantly influenced their movement (total distance travelled and mean daily movement). As far as the authors are aware, no comparable data exist on these analyses for noble crayfish by other authors. However, a relatively large amount of data can be found on invasive crayfish distribution and movement patterns. Bubb et al. (2002; 2004; 2006a) obtained similar results to ours for the relationship between signal crayfish size and movement, while research on Pacifastacus leniusculus by Guan and Wiles (1997), and Light (2003), and research on Procambarus clarkii by Gherardi et al. (2002) showed the opposite. Furthermore, no significant influence of sex on crayfish movement was established in the studies on signal crayfish (Bubb et al., 2002; 2004), and on red swamp crayfish (Gherardi et al., 2000; 2002), while the opposite was reported in the work by Light (2003).

Both upstream and downstream movements were recorded with no significant difference between directions - although upstream movements were more frequently recorded at both localities. The same was recorded in the work by Bubb et al. (2006a), Momot (1966) and Light (2003), while in the work by Guan and Wiles (1997), and Gherardi et al. (1998) no prevalence in upstream/downstream patterns was recorded.

More frequent records of upstream movements at both localities can probably be attributed to drought periods. The Velika Paklenica Stream is a torrent watercourse severely affected by weather conditions and drought, especially in the period from July to September when increased crayfish activity can be observed. Drought periods are known to last up to several months. One of the chosen localities (Anića luka at $270 \mathrm{~m}$ above sea level) had dried out completely in August 2002 and partially in September 2002. If drought and watercourse periodicity place environmental stress on the Velika Paklenica noble crayfish population, in future research we could expect to find reduced crayfish populations dominated by adults of smaller size, and low survival (Taylor, 1983).

Total distance travelled and mean daily movement did not differ significantly between upstream and downstream directions. It was observed that larger specimens were moving downstream more often. We would expect that the crayfish size is positively correlated with the capacity for upstream movement, e.g. movement against flow. However, it is possible that higher drag associated with large body size results in a tendency for larger specimens to move downstream, as downstream movements are energetically less demanding (Robinson et al., 2000; Light, 2003).

Crayfish captured repetitively in the same trap accounted for $5.45 \%$ of the analysed population in Anića and $11.11 \%$ in Hrast. The sex ratios for these recaptures were equal and their average size was $10.10 \mathrm{~cm}$ and $9.49 \mathrm{~cm}$, for males and females, respectively. Noble crayfish females reach sexual maturity at a size that ranges from $6.2 \mathrm{~cm}$ total length in localities with early maturity or slow growth to $8.5 \mathrm{~cm}$ total length in localities with late maturity or fast growth. Males become sexually mature at a size of $6.0-7.0 \mathrm{~cm}$ total length (Skurdal and Taugbøl, 2002). Therefore, recaptures in our research were mostly mature specimens that did not move far away from their shelters, which corresponds to the finding by Cukerzis (1988) that females and old males stay close to their burrows.

\section{CONCLUSION}

For the first time data on spatio-temporal behaviour are presented for the noble crayfish in natural populations using the mark-recapture method, and based upon a relatively large number of individuals. The data showed aggregated distribution patterns of the crayfish population in the researched habitat and considerable individual variation in movement, and confirmed that movement patterns are not size- or sex-dependent. Although not statistically 
significant, the upstream movement tendency was observed more frequently in our research. Observed movement patterns in the Velika Paklenica population, coupled with other traits, such as fecundity, growth and abiotic tolerances, can give complete information of population persistence in a relatively unfavourable habitat.

\section{ACKNOWLEDGEMENTS}

We would like to thank Dr. Gordan Lukač, Duje, Petra, Nika, Veljko, Nives and Sandro for their help during the fieldwork. Special thanks to Nika Galic for organisation of the fieldwork in 2000, and to the referees whose comments helped improve this manuscript.

\section{REFERENCES}

Abrahamsson S.A.A., 1966. Dynamics of an isolated population of the crayfish Astacus astacus Linné. Oikos, 17, 96-107.

Acosta C.A. and Perry S.A., 2001. Impact of hydropattern disturbance on crayfish population dynamics in the seasonal wetlands of Everglades National Park, USA. Aquat. Conserv. Mar. Freshw. Ecosyst., 11, 45-57.

Acquistapace P. and Gherardi F., 1999. Foraging activity in the white-clawed crayfish Austropotamobius pallipes. Freshwater Crayfish, 12, 915-916.

Aquiloni L., Ilhéu M. and Gherardi F., 2005. Habitat use and dispersal of the invasive crayfish Procambarus clarkii in ephemeral water bodies of Portugal. Mar. Freshw. Behav. Physiol., 38, 4, 225-236.

Barbaresi S. and Gherardi F., 2006. Experimental evidence for homing in the red swamp crayfish, Procambarus clakii. Bull. Fr. Pêche Piscic., 380-381, 1145-1154.

Barbaresi S., Salvi G. and Gherardi F., 1999. Daily activity in the white-clawed crayfish Austropotamobius pallipes: Field and laboratory studies. Freshwater Crayfish, 12, 918.

Barbaresi S., Tricarico E., Santini G. and Gherardi F., 2004. Ranging behaviour of the invasive crayfish Procambarus clakii. J. Nat. Hist., 38, 2821-2832.

Bohl E., 1987. Comparative studies on crayfish brooks in Bavaria (Astacus astacus L., Austropotamobius torrentium Schr.). Freshwater Crayfish, 7, 287-294.

Bohl E., 1997. An isolated population of the white-clawed crayfish (Austropotamobius pallipes) in the Principality of Liechtenstein. Bull. Fr. Pêche Piscic., 347, 701-712.

Bohl E., 1999. Motion of individual noble crayfish Astacus astacus in different biological situations: in situ studies using radio telemetry. Freshwater Crayfish, 12, 677-687.

Božičević S., 1999. Hidrološke specifičnosti vodotoka u Paklenici. Priroda, 89, 868, 9.

Brown D.J. and Bowler K., 1977. A population study of the British freshwater crayfish Austropotamobius pallipes (Lereboullet). Freshwater Crayfish, 3, 33-49.

Bubb D.H., Lucas M.C. and Thom T.J., 2002. Winter movements and activity of signal crayfish Pacifastacus leniusculus in an upland river, determined by radio telemetry. Hydrobiologia, 483, 1-3, 111-119.

Bubb D.H., Thom T.J. and Lucas M.C., 2004. Movement and dispersal of the invasive signal crayfish Pacifastacus leniusculus in upland rivers. Freshw. Biol., 49, 3, 357-368.

Bubb D.H., Thom T.J. and Lucas M.C., 2006a. Movement patterns of the invasive signal crayfish determined by PIT telemetry. Can. J. Zool., 84, 1202-1209.

Bubb D.H., Thom T.J. and Lucas M.C., 2006b. Movement, dispersal and refuge use of co-occurring introduced and native crayfish. Freshw. Biol., 51, 7, 1359-1368.

Byrne C.F., Lynch J.M. and Bracken J.J., 1999. A sampling strategy for stream populations of whiteclawed crayfish, Austropotamobius pallipes (Lereboullet) (Crustacea, Astacidae). Biol. Environ., 99B, 2, 89-94.

Cukerzis J.M., 1988. Astacus astacus in Europe. In: Holdich D.M. and Lowerry R.S. (eds.), Freshwater Crayfish: Biology, Management and Exploitation, Croom Helm, London, 309-340.

Faller M., 2006. Značajke populacije rijčenog raka (Astacus astacus L.) u slivu rijeke Orljave. Graduation thesis, University of Zagreb. 43 p. (in Croatian with English abstract).

Foster J., 1995. Factors influencing the distribution and abundance of the crayfish Austropotamobius pallipes (Lereboullet) in Wales and the Marches, U.K. Freshwater Crayfish, 8, 78-98. 
Gherardi F., Barbaresi S. and Villanelli F., 1998. Movement patterns in the white-clawed crayfish, Austropotamobius pallipes, in a Tuscan stream. J. Freshwater Ecol., 13, 413-424.

Gherardi F., Raddi A., Salvi G. and Barbaresi S., 1999. The use of territory in the red swamp crayfish Procambarus clarkii: spatial and temporal patterns. Freshwater Crayfish, 12, 931.

Gherardi F., Barbaresi S. and Salvi G., 2000. Spatial and temporal patterns in the movement of Procambarus clarkii, an invasive crayfish. Aquat. Sci., 62, 179-193.

Gherardi F., Tricarico E. and Ilheu M., 2002. Movement patterns of an invasive crayfish, Procambarus clarkii, in a temporary stream of southern Portugal. Ethol. Ecol. Evol., 14, 3, 183-197.

Guan R.Z., 1997. An improved method for marking crayfish. Crustaceana, 70, 6, 641-652.

Guan R.Z. and Wiles P., 1997. The home range of signal crayfish in a British lowland river. Freshw. Forum, 8, 45-54.

Hogger J.B., 1988. Ecology, population biology and behaviour. In: Holdich D.M. and Lowery R.S. (eds.), Freshwater Crayfish: Biology, Management and Exploitation, The University Press, Cambridge, 114-144.

Krebs C.J., 1989. Estimating Abundance: Mark-and-Recapture Techniques. In: Wilson C.M. (ed.), Ecological Methodology, Harper \& Row, Publishers, New York, 15-64.

Laurent P.J., 1988. Austropotamobius pallipes and A. torrentium, with observations on their interactions with other species in Europe. In: Holdich D.M. and Lowery R.S. (eds.), Freshwater Crayfish: Biology, Management and Exploitation, The University Press, Cambridge, 309-340.

Light T., 2003. Success and failure in a lotic crayfish invasion: the roles of hydrologic variability and habitat alternation. Freshw. Biol., 48, 1886-1897.

Lucić A., 2004. Fiziološka obilježja tri vrste slatkovdnih rakova iz porodice Astacidae. Ph.D. thesis, University of Zagreb, 122 p. (in Croatian with English abstract).

Maguire I., 2002. Porodica Astacidae u sjeverozapadnoj Hrvatskoj. Ph.D. thesis, University of Zagreb, 128 p. (in Croatian with English abstract).

Maguire I. and Gottstein-Matočec S., 2004. The distribution pattern of freshwater crayfish in Croatia. Crustaceana, 77, 1, 25-49.

Momot W.T., 1966. Upstream movements of crayfish in an intermittent Oklahoma stream. Am. Midl. Nat., 75, 150-159.

Myers J.H., 1978. Selecting a measure of dispersion. Environ. Entomol., 7, 619-621.

Narodne Novine, 70/05 Zakon o zaštiti prirode.

Narodne Novine, 7/06 Pravilnik o proglašavanju divljih svojti zaštićenim i strogo zaštičenim.

Niemi A., 1977. Population studies on the crayfish Astacus astacus L. in the River Pyhäjoki, Finland. Freshwater Crayfish, 3, 81-94.

Odelström T., 1988. The food choice of the crayfish Astacus astacus L. in relation to environmental conditions. Ph.D. thesis, University of Uppsala, Sweden.

Okubo A. and Levin S.A., 2001. Diffusion and ecological problems. Springer-Verlag, New York, Inc., $459 \mathrm{p}$.

Pielou E.C., 1977. Mathematical ecology, Wiley, New York.

Robinson C.A., Thom T.J. and Lucas M.C., 2000. Ranging behaviour of a large freshwater invertebrate, the white-clawed crayfish Austropotamobius pallipes. Freshw. Biol., 44, 509-521.

Schütze S., Stein H. and Born O., 1999. Radio telemetry observations on migration and activity patterns of restocked noble crayfish Astacus astacus (L.) in the small River Sempt, north-east of Munich, Germany. Freshwater Crayfish, 12, 688-695.

Skurdal J. and Taugbøl T., 2002. Astacus. In: Holdich D.M. (ed.), Biology of Freshwater Crayfish, Blackwell Science, Oxford, 467-510.

Skurdal J., Fjeld E., Hessen D.O., Taugbøl T. and Dehli E., 1988. Depth distribution, habitat segregation and feeding of the crayfish Astacus astacus in Lake Steinsfjorden. Nordic J. Freshw. Res., 64, 113-119.

Skurdal J., Qvenild T. and Taugbøl T., 1992. Mark-recapture experiments with noble crayfish (Astacus astacus) in a Norwegian lake. Aquaculture and Fisheries Management, 23, 187-193.

Sutherland W.J., 1996. From Individual Behaviour to Population Ecology, Oxford University Press, Oxford.

Taylor R.C., 1983. Drought-induced changes in crayfish populations along a stream continuum. Am. Midl. Nat., 110, 286-298.

Westin L. and Gydemo R., 1989. Variation in sex ratio in the noble crayfish Astacus astacus: a reflection of yearly activity changes. Freshwater Crayfish, 7, 115-120.

Westman K., Pursiainen M. and Vilkman R., 1978. A new folding trap model which prevents crayfish from escaping. Freshwater Crayfish, 4, 235-242. 